\title{
ANALISA DAMPAK PANDEMI COVID-19 TERHADAP JUMLAH KUNJUNGAN PADA SITUS E-COMMERCE DI INDONESIA MENGGUNAKAN UJI T BERPASANGAN
}

\section{ANALYSIS OF THE IMPACT OF THE COVID-19 PANDEMIC ON THE NUMBER OF VISITS ON E-COMMERCE SITES IN INDONESIA USING PAIRED T TEST}

\author{
Dewi Hernikawati \\ Kementerian Komunikasi dan Informatika \\ Jl. Pegangsaan Timur No. 19b, Jakarta Pusat, Indonesia \\ dewi005@kominfo.go. \\ Diterima tgl. 11/10/2021; Direvisi tgl. 25/11/2021; Disetujui tgl. 03/12/2021
}

\begin{abstract}
During the COVID-19 pandemic, the government implemented a Large-Scale Social Restriction (PSBB) policy to suppress the spread of the Coronavirus in Indonesia. These restrictions make the community unable to travel and carry out activities. This condition triggers new habits to adapt to the existing conditions. Activities to fulfil basic needs previously carried out by direct shopping have turned online. E-commerce is needed to meet these needs. This study will see differences in visits to e-commerce sites in Indonesia. The method used is a quantitative approach using website visit data before and during the COVID-19 pandemic. JASP was used to process the data. The data testing used the t-test for paired samples. The result is that there is a difference in average website visits before the COVID-19 pandemic and during the Covid 19 pandemic. The COVID-19 pandemic affects the number of e-commerce website visits. Shopee and Tokopedia are e-commerce sites that experienced an increase in the number of visits during the COVID19 pandemic. The impact of this increase in visits to e-commerce sites is an increase in online financial transactions, demand for expedition services, the need for materials to package goods, and the need for labour in expedition services.
\end{abstract}

Keywords: Covid 19, e-commerce, visit

\section{ABSTRAK}

Pada masa Pandemi COVID-19 ini pemerintah menerapkan kebijakan Pembatasan Sosial Berskala Besar (PSBB) untuk menekan laju penyebaran virus Corona di Indonesia. Pembatasan ini mengakibatkan masyarakat menjadi tidak bebas untuk bepergian dan berkegiatan. Kondisi ini memicu munculnya kebiasaan baru untuk beradaptasi dengan kondisi yang ada. Kegiatan pemenuhan kebutuhan pokok yang sebelumnya dilakukan dengan belanja secara langsung berubah menjadi tidak langsung (online). Pemenuhan kebutuhan pokok dengan online ini membutuhkan $e$-commerce. E-commerce adalah kegiatan jual dan beli barang secara elektronik. Dengan perubahan perilaku masyarakat tersebut maka penelitian ini akan melihat apakah ada perbedaan kunjungan pada situs e-commerce di Indonesia. Metode yang digunakan adalah pendekatan kuantitatif dengan menggunakan data kunjungan website sebelum dan selama pandemi COVID-19. Data diolah dengan bantuan software JASP. Pengujian data menggunakan uji perbedaan rata-rata t-tes untuk sampel berpasangan. Hasilnya adalah terdapat perbedaan rata-rata kunjungan website sebelum pandemi COVID-19 dan selama pandemi Covid 19. Pandemi COVID-19 berpengaruh terhadap jumlah kunjungan website e-commerce. Shopee dan Tokopedia merupakan situs e-commerce yang mengalami peningkatan jumlah kunjungan selama masa pandemi COVID-19. Dampak peningkatan kunjungan situs $e$ commerce ini adalah terjadi peningkatan transaksi keuangan secara online, permintaan jasa ekspedisi yang meningkat, kebutuhan bahan untuk mengemas barang meningkat, dan peningkatan kebutuhan tenaga kerja pada jasa ekspedisi.

Kata Kunci: COVID-19, e-commerce, kunjungan 


\section{PENDAHULUAN}

Pemerintah Indonesia menerapkan kebijakan Pembatasan Sosial Berskala Besar (PSBB) pada masa pandemi COVID-19 ini. Pembatasan ini bertujuan untuk menekan penyebaran virus Corona di Indonesia. Dengan pembatasan ini masyarakat menjadi tidak leluasa untuk melakukan kegiatan dan perjalanan ke daerah lain. Kondisi ini memicu munculnya kebiasaan baru untuk beradaptasi dengan kondisi yang ada. Jika sebelum ada pandemi COVID-19 dan PSBB, masyarakat bebas melakukan aktivitasnya baik untuk bekerja, kegiatan sosial, sekolah, kegiatan ekonomi maka dengan adanya pembatasan ini kebiasaan-kebiasaan yang biasa diakukan menjadi tidak bisa dilakukan. Sebagai contoh jika sebelum COVID-19 masyarakat bebas berkunjung ke pasar, supermarket atau pergi ke mal untuk memenuhi kebutuhan pokoknya maka sejak adanya pandemi COVID-19, masyarakat dilarang untuk bepergian keluar rumah jika tidak ada kebutuhan yang mendesak serta terdapat pembatasan jam operasional dari pasar dan tempat perbelanjaan. Selain itu Pemerintah juga menerapkan protokol Kesehatan atau SOP yang ketat.

Protokol Kesehatan yang harus dilakukan yaitu mencuci tangan sebelum memasuki suatu gedung, pengukuran suhu tubuh untuk mengetahui kondisi kesehatan dengan screening awal suhu badan yang tidak boleh melebihi 37,5 derajat celcius, kewajiban untuk memakai masker guna mencegah penularan COVID-19 melalui droplet saat batuk ataupun bersin, dan menjaga jarak. Tidak hanya itu, Pemerintah juga menghimbau masyarakat untuk memakai lengan panjang dan celana atau rok panjang yang menutup semua permukaan kulit. Pembatasan jumlah pengunjung pada suatu mal atau pasar juga dilakukan agar jarak antar pengunjung bisa dijaga. Dengan pembatasan pengunjung di suatu tempat ini menimbulkan antrian diluar gedung dan waktu banyak terpakai untuk mengantri sehingga masyarakat menjadi malas untuk bepergian jika tidak ada terpaksa.

Kebijakan yang diberlakukan pemerintah ini menimbulkan dampak atau berpengaruh pada berbagai bidang seperti bidang ekonomi, sosial, pendidikan, budaya, kesehatan, dan sebagainya. Pada bidang ekonomi salah satu dampak yang terjadi adalah berubahnya pola belanja masyarakat dari belanja langsung menjadi belanja tidak langsung (online) dalam pemenuhan kebutuhan pokok dan untuk kepentingan hariannya. Pola belanja yang berubah ini berdampak pada penjual, yaitu penjual konvensional menjadi kurang laku karena pembeli beralih ke belanja online. Kondisi ini menuntut penjual untuk segera beradaptasi dengan pembiasaan baru agar tetap bisa bertahan. Pedagang dituntut untuk melakukan perdagangan secara online. Langkah yang bisa dilakukan pedagang untuk mensiasati perubahan ini antara lain dengan bergabung pada market place, memasarkan barang-barang melalui media sosial, bergabung dengan aplikasi online (gojek, grab) atau membuat website sendiri.

Facebook, Instagram, dan twitter merupakan media sosial yang banyak digunakan masyarakat untuk memasarkan produk-produknya dan digunakan untuk berjualan. Pada media sosial facebook terdapat banyak grup-grup dengan kesamaan minat atau hobi, grup jual beli, grup sosial, dan lainlain yang bisa dimanfaatkan sebagai media untuk memasarkan dan menjual produk dagangan. Saat ini facebook dengan fasilitas marketplace digunakan oleh UMKM untuk memperluas pemasaran dan menjadi media promosi gratis karena memiliki jangkauan yang luas dan tidak terbatas ruang dan waktu. Keuntungan yang diperoleh UMKM dengan menggunakan facebook marketplace ini antara lain pelaku UMKM lebih mudah untuk memasarkan produk dan menjualnya hanya dengan memakai smartphone sehingga pendapatan yang diperoleh dari penjualan produk meningkat (Susanto et al., 2020). Kelebihan yang dimiliki facebook untuk media promosi adalah tersedia fitur informasi seperti umur, lokasi, hobi yang bisa digunakan untuk menentukan segmentasi pasar; bisa menyaring pangsa pasar karena pengguna memiliki informasi yang bisa digunakan sehingga bisa fokus untuk segmentasi pasar; pengguna bisa mengakses facebook setiap saat dengan perangkat 
yang dimiliki baik smartphone, laptop, atau computer asal terhubung dengan jaringan internet; memudahkan dalam berkomunikasi dengan memanfaatkan fitur pesan (message), obrolan (chat), dan lain-lain; pembeli bisa memberikan umpan balik (feed back) terhadap barang yang dibeli dengan menyampaikan kritik dan saran kepada penjual secara langsung; dapat berguna sebagai alat komunikasi sehingga selalu terhubung sehingga hubugan bisnisnya terjaga dengan baik; facebook bisa digunakan dengan gratis yang memberikan dampak besar dalam pemasaran sehingga menguntungkan penjual; cara pemasaran yang baru dan memasuki era New Wave Marketing dengan facebook sebagai salah satu penyebab utamanya (Muttaqin, 2012).

Selain itu, Instagram menjadi salah satu pilihan yang banyak digunakan dan popular untuk memasarkan produk dan bisa memperluas jangkauan pemasaran saat ini. Instagram memiliki kelebihan dalam menarik pembeli karena mudah yaitu dengan memasang foto produk atau barang yang akan dijual di akun instagaram sebagai penawaran atau iklan. Dengan banyaknya follower di akun Instagram yang dimiliki semakin memudahkan seseorang dalam berjualan karena dengan memanfaatkan follower yang banyak ini bisa dijadikan target untuk memasarkan suatu produk. Salah satu contoh pengguna Instagram adalah Dollies dengan akun Instagram @ weardollies untuk memasarkan produk fashion ke seluruh Indonesia dan tidak terbatas hanya di Bandung sehingga omset penjualannya meningkat (Supratman \& Rachmansyah, 2020).

Selama penerapan social distancing terjadi peningkatan volume transaksi perdagangan di perusahaan-perusahaan e-commerce di Indonesia (Dinisari, 2020). Berdasarkan data dari BPS, pandemi COVID-19 berdampak pada penurunan pendapatan lebih dari 75 persen sebanyak 25,53 persen pelaku usaha yang terdampak besar pada usaha penyedia akomodasi dan penyedia makanan dan minuman. Untuk usaha yang mengalami peningkatan pendapatan lebih dari 75 persen yaitu usaha untuk skala perdagangan besar dan eceran, perbaikan dan perawatan untuk kendaraan seeperti mobil dan sepeda motor. (Kusumatrisna, et all 2020).

E-commerce memiliki peran dalam bidang ekonomi bagi pelaku usaha, konsumen, dan pemerintah selama masa Pandemi COVID-19 (Ayu \& Lahmi, 2020). Perubahan pola perilaku masyarakat terjadi pada masa pandemi COVID-19 yaitu dengan berbelanja online untuk memenuhi kebutuhan hidupnya (Permana et al. 2021). Faktor kenyamanan merupakan alasan masyarakat beralih untuk berbelanja online. Kenyamanan berbelanja ini dibedakan menjadi dua jenis yaitu kenyamanan bisa melakukan transaksi tanpa harus keluar rumah dan transaksi bisa dilakukan selama 24 jam. Faktor-faktor utama yang mempengaruhi perilaku masyarakat Indonesia dalam berbelanja online adalah kepercayaan, harga, kenyamanan, dan ketersediaan barang. Faktor lain yang juga berpengaruh terhadap perilaku berbelanja online masyarakat adalah kualitas suatu produk yang baik, keamanan dalam melakukan transaksi, desain website yang mudah digunakan, dan perilaku konsumtif dari masyarakat yang suka berbelanja (Harahap, 2018). Sedangkan faktor utama untuk berbelanja online negara-negara di Eropa adalah kepuasan pelanggan, selain itu waktu pengiriman barang dengan standar yang tinggi, dan harga yang lebih murah dibandingkan dengan berbelanja langsung (Majchrzak-Lepczyk, 2021).

Bisnis e-commerce di Indonesia mengalami peningkatan sebesar 5-10 kali lipat selama pandemi COVID-19 peningkatan pelanggan baru yang mencapai 51\% namum proses pengiriman atau distribusi barang mengalami keterlambatan karena pembatasan transportasi selama lockdown(Laming, 2020).

E-commerce atau perdagangan elektronik adalah semua kegiatan jual beli yang dilakukan dengan media elektronik seperti televisi, radio, namun dengan perkembangan teknologi dan saat ini e-commerce lebih banyak dilakukan dengan menggunakan internet. Pada media baru e-commerce dapat diartikan sebagai transaksi penjualan dan pembelian barang memakai media elektronik dan penggunaan internet lebih banyak untuk kondisi sekarang. E-commerce pada media baru lebih 
mementingkan komunikasi yang interaktif sehingga komunikasi dua arah bisa dengan mudah terjadi, dan informasi tersedia dengan mudah untuk dicarinya, serta pengguna bisa menggunakan halaman dengan praktis. Ciri lain pada penggunaan media baru ini adalah dispersal yaitu penyedia e-commerce yang sudah besar hanya berperan sebagai penyedia halaman kepdada pengguna untuk melakukan penjualan dan penjual juga bisa menjadi pembelinya (Muktaf, 2016).

Pengertian e-commerce adalah otomisasi prosedur pada proses bisnis dan operasi secara rutin yang ditransformasi menjadi virtual sehingga meningkatkan efisiensi dan proses bisnis (Išoraitė \& Miniotiené, 2018). E-commerce dalam pandangan yang lain adalah saluran distribusi yang berkembang secara dinamis dan menjadi sumber pendapatan utama bagi suatu perusahaan serta menjadi saluran komunikasi utama dengan konsumen dalam menawarkan solusi untuk memenuhi kebutuhan konsumen (Majchrzak-Lepczyk, 2021). Berdasarkan pengertian diatas dapat disimpulkan bahwa e-commerce merupakan transaksi jual beli suatu produk dengan menggunakan media internet sehingga terwujud otomatisasi prosedur pada proses bisnis sehingga meningkatkan efisiensi dan bisa menjadi sumber pendapatan utama bagi suatu perusahaan dan menjadi solusi bagi pembeli untuk memenuhi kebutuhannya secara mudah dan praktis.

Perkembangan teknologi informasi dan komunikasi yang sangat pesat saat ini menjadikan $e$ commerce sebagai pilihan karena memiliki banyak keuntungan baik dari segi konsumen, penjual, dan masyarakat. Keuntungan yang diperoleh konsumen antara lain waktu untuk berbelanja yang fleksibel tersedia 7 hari selama 24 jam, tidak perlu antri, bisa dilakukan dirumah tanpa perlu pergi dan mengelurkan uang untuk transportasi, semua kebutuhan bisa terpenuhi, dan tersedia barang dari seluruh dunia dengan harga yang kompetitif dan banyak pilihan (Kurtz, 2016). Bagi penjual keuntungan yang diperoleh dengan adanya e-commerce adalah adanya peningkatan penghasilan bagi penjual, biaya operasi dan pemeliharaan bisa berkurang, biaya pembelian dan pengadaan barang juga mengalami pengurangan biaya, loyalitas pelanggan yang meningkat dan akan selalu belanja ditempat yang sama, biaya transportasi yang dikeluarkan bisa dikurangi, bisa memelihara dan mengembangkan hubungan baik antara pelanggan dan pemasok barang-barang, proses penjualan yang dapat ditingkatkan kecepatannya, hubungan komunikasi di internal dan eksternal bisa lebih ditingkatkan, serta meningkatkan citra dan merk perusahaan (Khan, 2016).

Dengan adanya e-commerce ini memberikan keuntungan atau dampak positif dalam kegiatan pemasaran antara lain promosi produk dan jasa menjadi lebih mudah dilakukan secara interaktif dan real time dengan menggunakan internet, distribusi barang menjadi lebih luas jangkauanannya, informasi produk bisa dikirimkan secara digital sehingga menghemat biaya, bisa menghemat waktu untuk pekerjaan administratif utamanya untuk pemasaran secara internasional yang dimulai dari pemesanan suatu barang sampai pengiriman produk yang dipesan, pelanggan lebih puas karena mendapat pelayanan yang lebih responsif untuk memperoleh informasi secara mjendetail dan respon langsung secara online, dapat menerapkan mass customization pada produk yang akan dipasarkan contohnya mobil, rumah, komputer, kosmetik, kartu ucapan, kaos, dan lain-lainnya, biaya dan waktu menjadi lebih hemat dalam memproses suatu pesanan, serta dapat memberikan pasar maya/virtual sehingga bisa menawarkan produknya dengan bebas (Wibowo, 2016). Keuntungan yang diperoleh bagi masyarakat dengan adanya e-commerce yaitu konsumen tidak perlu berpindah-pindah tempat untuk berbelanja sehingga biaya untuk transportasi atau pergerakan masyarakat menjadi lebih sedikit yang berakibat pada pengurangan polusi udara. Selain itu konsumen dengan pendapatan rendah lebih diuntungkan karena bisa membayar dengan harga yang lebih murah untuk barang-barang yang dibutuhkan dan konsumen dari daerah terpencil bisa mendapatkan barang dari luar kota, hal yang tidak mungkin jika tidak ada e-commerce (Taher, 2021). 
Berdasarkan penelitian yang dilakukan oleh (Pradana, 2015) terdapat 6 (enam) jenis website $e$ commerce di Indonesia yang dikelompokkan menjadi website untuk memasang iklan baris/listing, situs jual beli online (online marketplace), shopping mall, toko online yang bisa memanfaatkan media sosial, dan berbagai jenis website crowdsourcing. E-commerce untuk Listing/iklan baris yang ada di Indonesia adalah OLX, dan berniaga.com. Untuk model e-commerce online marketplace yang ada di Indonesia saat ini adalah tokopedia, bukalapak, dan shoppe. Blibli dan Zalora merupakan contoh untuk e-commerce shopping mall yang ada di Indonesia. Toko online di Indonesia dapat dicontohkan oleh Lazada.com dan Bhinneka.com. Toko online di media sosial dapat dicontohkan yaitu pemilik akun media sosial facebook, Instagram, atau twitter yang menggunakannya untuk mempromosikan dan menjual barang-barang dagangannya. Sedangkan untuk contoh website crowdsourcing dan crowdfunding adalah Kitabisa.com, wujudkan.com

Uji t-tes sampel berpasangan merupakan suatu metode yang digunakan untuk melakukan uji hopotesis pada data berpasangan yaitu data yang tidak bebas. Data berpasangan dimaksudkan sebagai satu individu atau obyek penelitian yang mendapatkan dua perlakuan yang berbeda (Montolalu \& Langi, 2018). Jadi uji t-tes yang dilakukan pada sampel berpasangan ini adalah untuk melihat apakah ada perbedaan suatu sampel jika mendapatkan perlakuan yang berbeda. Pengujian sampel berpasangan dilakukan memiliki tujuan untuk melakukan analisis apakah dua sampel yang saling berpasangan mempunyai perbedaan, untuk melakukan pengujian apakah sampel berpasangan tersebut mempunyai karakteristik atau ciri-ciri yang sama, untuk mengetahui apakah perlakuan berbeda yang diberikan pada sampel mempunyai pengaruh yang sama, dan untuk melihat apakah ada pengaruh yang lebih baik setelah diberikan perlakuan untuk sampel (Heryana, 2017).

Berdasarkan pada latar belakang yang sudah dipaparkan diatas yaitu dengan adanya Pembatasan Sosial Berskala Besar (PSBB) yang berakibat pada perubahan pola belanja masyarakat untuk memenuhi kebutuhan pokok sehari-harinya, ditunjang dengan penelitian terdahulu terhadap peranan e-commerce untuk berbelanja online dan teori e-commerce serta pengujian sampel berpasangan dengan menggunakan uji t-tes maka penelitian ini bertujuan untuk melihat apakah ada dampak pandemi COVID-19 terhadap market place. Permasalahan yang akan dijawab pada tulisan ini adalah apakah ada perbedaan kunjungan pada situs e-commerce sebelum dan selama pandemi COVID-19 dengan adanya pembatasan kegiatan yang mengakibatkan perubahan cara berbelanja ini.

\section{METODE PENELITIAN}

Penelitian ini menggunakan pendekatan kuantitatif dengan melakukan analisis untuk data numerical (angka) dan diolah dengan metode statistika. Sumber data pada penelitian ini adalah data sekunder yaitu data yang diperoleh dari pihak lain dan tanpa menyebarkan kuesioner pada responden. Data yang digunakan adalah data dari jumlah kunjungan pada situs e-commerce di Indonesia. Analisis data menggunakan uji t-tes untuk melihat perbedaan kondisi penggunaan situs e-commerce sebelum pandemi COVID-19 dan selama pandemi COVID-19. Pengolahan data dilakukan dengan bantuan software JASP. Pertimbangan yang digunakan dalam pemilihan JASP ini karena JASP adalah program open source yang bisa diperoleh dengan gratis.

Sebelum melakukan uji t-tes sampel berpasangan maka terlebih dahulu dilakukan Uji normalitas. Pengujian normalitas ini dilakukan untuk melihat sebaran data pada sebuah kelompok data atau variabel yaitu apakah data yang diperoleh berdistribusi normal atau tidak sehingga bisa digunakan dalam statististik parametrik. Namun jika hasil pengujian normalitas adalah data berdistribusi tidak normal maka pengujian bisa dilakukan dengan uji t-tes sampel berpasangan non parametrik. 
Data yang digunakan pada penelitian ini merupakan data pengunjung website e-commerce di Indonesia pada kuartal tiga dan kuartal empat tahun 2019 dan data pengunjung pada kuartal tiga dan kuartal empat pada tahun 2020. Jumlah sampel yang digunakan adalah 80 data kunjungan sebelum pandemi dan 80 data selama pandemi COVID-19.

Hipotesis yang akan dibuktikan pada tulisan ini adalah:

H0: Rata-rata kunjungan situs e-commerce sebelum pandemi COVID-19 dan selama pandemi COVID-19 tidak ada perbedaan jumlah kunjungan artinya pandemi COVID-19 tidak mempengaruhi jumlah pengunjung pada situs e-commerce di Indonesia

H1: Rata-rata kunjungan situs e-commerce sebelum pandemi COVID-19 dan selama pandemi COVID-19 terdapat perbedaan yang dapat diartikan bahwa pandemi COVID-19 mempengaruhi jumlah pengunjung pada situs e-commerce di Indonesia

\section{HASIL DAN PEMBAHASAN}

Untuk melihat gambaran data maka digunakan data pengunjung pada 7 situs e-commerce dengan pengunjung terbanyak sebelum pandemi dan selama pandemi COVID-19. Data yang digunakan untuk tingkat kunjungan sebelum pandemi COVID-19 pada kuartal ke tiga tahun 2019 sampai dengan selama pandemi COVID-19 pada kuartal ke empat tahun 2020. Situs e-commerce yang digunakan adalah Tokopedia, Bukalapak, Shopee, Lazada, Blibli, JDID, dan Orami.

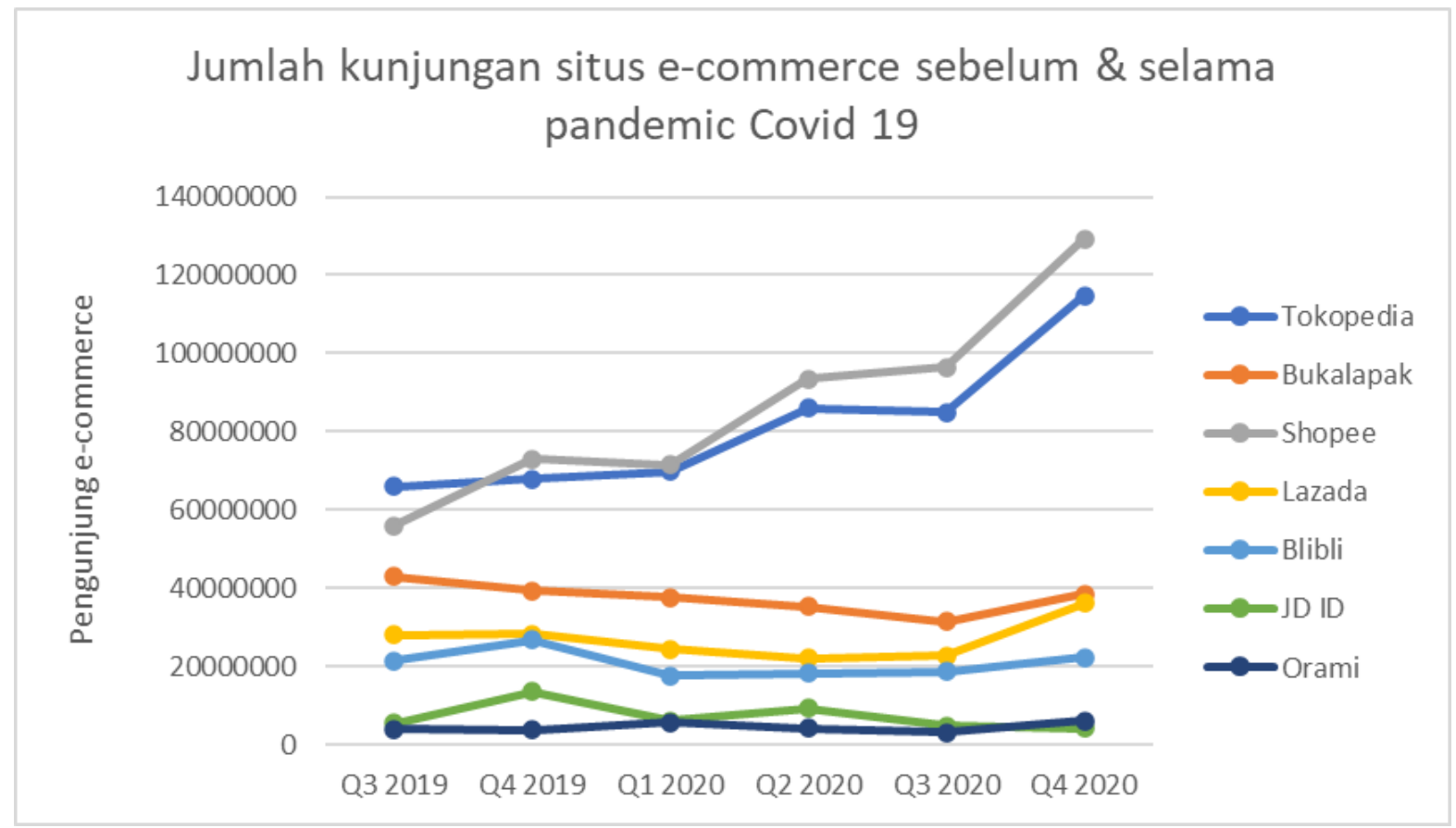

Gambar 1. Grafik jumlah kunjungan situs e-commerce sebelum dan selama pandemic COVID-19

Sumber: Data diolah dari Iprice Insights (2021)

Gambar 1. Menunjukkan bahwa terjadi peningkatan kunjungan pada situs e-commerce di Indonesia. Peningkatan kunjungan ini terlihat jelas pada Shopee dan Tokopedia sejak dari kuartal ketiga tahun 2019 sampai dengan kuartal ke-4 tahun 2020. Sebelum pandemi pada kuartal ke 3 terlihat bahwa kunjungan pada situs Shopee sebanyak 55,9 juta pengunjung dan meningkat menjadi diatas 129 juta pengunjung. Kenaikan jumlah pengunjung ini prosentasenya sangat tinggi yaitu sebesar 73,84\%. Pada kuartal 1 tahun 2020 Shopee dan Tokopedia memiliki jumlah pengunjung 
yang sama namun trend kunjungan di Shopee mengalami pertumbuhan yang lebih tinggi dibandingkan Tokopedia. Tokopedia di kuartal 3 tahun 2019 memiliki jumlah pengunjung yang lebih banyak daripada Shopee yaitu diatas 65,9 juta pengunjung namun pada kuartal 4 tahun 2020 sebesar 114,6 juta pengunjung, jumlah pengunjung ini lebih sedikit dibandingkan dengan Shopee. Kedua situs e-commerce Shopee dan Tokopedia menunjukkan pertumbuhan pengunjung yang sangat signifikan selama masa pandemi COVID-19 ini dibandingkan dengan situs-situs ecommerce yang lain.

Jumlah Pengunjung pada situs e-commerce ini tidak semua mengalami peningkatan jumlah dan terdapat situs-situs e-commerce yang jumlah kunjungannya menurun selama pandemic COVID-19. Kondisi naik dan turun jumlah kunjungan ini dapat dilihat pada situs Bukalapak yang memiliki tren menurun sejak tahun 2019 pada kuartal ketiga sampai dengan tahun 2020 di kuartal ke tiga. Kemudian pada kuartal ke empat tahun 2020 Bukalapak mengalami peningkatan namun jumlah pengunjungnya tidak sebanyak pada saat kuartal 3 tahun 2019. Jumlah pengunjung di Lazada juga berfluktuasi sebelum dan selama pandemi COVID-19. Hal ini dapat dilihat pada gambar 1 yang menunjukkan bahwa tahun 2019 jumlah pengunjung lebih banyak dibandingkan tahun 2020 pada kuartal 1 sampai kuartal 3. Di situs Lazada terjadi peningkatan jumlah pengunjung pada kuartal 4 tahun 2020 dengan kenaikan sebanyak 29,52\% dibandingkan dengan kuartal 3 tahun 2019. Pada situs blibli juga memiliki trend yang berubah-ubah yaitu pada kuartal 4 tahun 2019 mengalami peningkatan dibandingkan kuartal 3 tahun 2019 dan kemudian menurun pada kuartal 1 tahun 2020 serta meningkat kembali pada kuartal ke 2 sampai dengan kuartal 4 tahun 2020 dengan peningkatan yang sangat kecil 4,75\% jika dibandingkan dengan kuartal 3 tahun 2019.

Berdasarkan analisis perubahan jumlah pengunjung situs e-commerce tersebut terdapat situs yang mengalami kenaikan jumlah pengunjung dan penurunan jumlah pengunjung bahkan ada yang berfluktuasi dengan naik dan turun selama pandemi COVID-19. Oleh karena itu pada analisis selanjutnya akan dilihat apakah ada perbedaan jumlah kunjungan pada situs e-commerce sebelum dan selama masa pandemi COVID-19 dengan menggunakan uji T sampel berpasangan. Data yang digunakan pada uji $\mathrm{T}$ ini merupakan data kunjungan situs e-commerce pada kuartal 3 dan 4 tahun 2019 dan selama pandemic diambil data pada kuartal 3 dan 4 tahun 2020. Data yang digunakan pada penelitian ini sebanyak 80 data kunjungan sebelum pandemic dan 80 data selama pandemic COVID-19. Pengujian dilakukan dengan bantuan software JASP. JASP dipilih karena merupakan software open source sehingga bisa diperoleh dengan gratis dan memiiki tampilan yang sederhana.

Rata-rata kunjungan pada website e-commerce pada tahun 2019 pada kuartal 3 dan kuartal 4 adalah 6.775.240 dan untuk rata-rata kunjungan website pada tahun 2020 pada kuartal 3 dan kuartal 4 adalah 8.188.000. Hal ini menunjukkan bahwa terjadi peningkatan kunjungan pada masa pandemi dibandingkan sebelum adanya pandemi Covid 19. Standar deviasi pada kunjungan website tahun 2019 menunjukkan nilai 16.040 .000 dan pada tahun 2020 sebesar 24.230 .000 dapat diartikan bahwa sebaran data terhadap nilai rata-ratanya pada tahun 2020 lebih besar jika dibandingkan sebaran data tahun 2019.

Tabel 1. Statistik diskriptif

\section{Descriptives}

\begin{tabular}{|c|c|c|c|c|}
\hline & $\mathbf{N}$ & Mean & SD & SE \\
\hline traffic 2019 & 80 & $5.775 e+6$ & $61.604 \mathrm{e}+$ & $\begin{array}{lll}+7 & 1.793 \mathrm{e}+6\end{array}$ \\
\hline traffic 2020 & 80 & $3.188 \mathrm{e}+6$ & $62.423 \mathrm{e}+$ & $+7 \quad 2.709 \mathrm{e}+6$ \\
\hline
\end{tabular}

Sumber: Data diolah dari Iprice Insights (Insight, 2021) 
Uji normalitas dilakukan untuk mengukur data apakah berdistribusi normal atau tidak sehingga bisa diambil keputusan untuk melakukan pengujian selanjutnya yaitu uji t-tes parametrik atau uji t-tes non parametrik. Berdasarkan nilai yang diperoleh dari hasil uji normalitas dengan Shapiro-Wilk menghasilkan nilai p lebih kecil dari 0 yang dapat diartikan bahwa asumsi untuk pengujian tes normal tidak terpenuhi sehingga pengujian beda rata-rata dengan uji t tidak bisa dilakukan untuk uji t parametrik dan pengujian selanjutnya dengan uji t untuk non parametrik. Pada data yang sudah diuji normalitasnya menghasilkan data berdistribusi tidak normal maka pengujiannya menggunakan uji Wilcoxon's signed-rank (Sampson, 2019). Hasil pengujian untuk tes normalitas terlihat pada tabel 2. Uji normalitas.

Tabel 2. Uji normalitas

Test of Normality (Shapiro-Wilk)

\begin{tabular}{llll}
\hline & W & p \\
\hline traffic 2019 & - traffic 2020 & 0.378 & $<.001$ \\
\hline
\end{tabular}

Note. Significant results suggest a deviation from normality.

Sumber: Data diolah dari Iprice Insights (Insight, 2021)

Kriteria signifikan untuk uji dengan t-tes pada sampel berpasangan adalah untuk nilai $\mathrm{p}<0.05$ maka hasil pengujian yang dilakukan hasilnya signifikan. Berdasarkan hasil pengujian dengan uji ttes non parametrik Wilcoxon's signed-rank menunjukkan nilainya kurang atau lebih kecil dari 0.001 dan berdasarkan kriteria uji t tersebut nilainya lebih kecil dari 0.05 maka hasil pengujian yang dilakukan adalah signifikan. Dengan demikian dapat dikatakan bahwa rata-rata kunjungan situs e-commerce sebelum pandemi COVID-19 dan selama pandemi COVID-19 memiliki perbedaan jumlah pengunjung.

Pada parameter estimasi Hodges-Lehman Estimate menunjukkan perbedaan nilai median kunjungan situs e-commerce pada tahun 2019 dan kunjungan e-commerce tahun 2020 sebesar 220.893,222. Untuk nilai korelasi Rank-Biserial adalah besaran efek dan memiliki interprestasi yang sama seperti korelasi Pearson. Berdasarkan hasil pengujian tersebut nilai korelasi RankBiserial sebesar 0,475 sehingga pandemic COVID-19 ini memiliki pengaruh atau efek yang besar terhadap situs e-commerce.

Tabel 3. Uji t-tes kunjungan e-commerce sebelum dan selama pandemic Covid19 Paired Samples T-Test

\begin{tabular}{lllllll}
\hline Measure 1 & Measure 2 & W & df & $\mathbf{p}$ & $\begin{array}{c}\text { Hodges-Lehmann } \\
\text { Estimate }\end{array}$ & Rank-Biserial Correlation \\
\hline traffic & traffic & 2289.000 & $<.001$ & & 220893.222 & 0.475 \\
2019 & 2020 & 23800 & & & & \\
\hline
\end{tabular}

Note. Wilcoxon signed-rank test.

Sumber: Data diolah dari Iprice Insights (Insight, 2021)

Dengan hasil pengujian tersebut maka terdapat pengaruh pandemi COVID-19 terhadap jumlah kunjungan masyarakat pada website e-commerce. Pola belanja masyarakat dari yang sebelumnya melakukan belanja secara langsung dan bertatap muka berubah menjadi belanja online. Dengan belanja online ini memberikan dampak perubahan yang besar pada sektor ekonomi. Sektor-sektor yang terpengaruh antara lain pada jumlah peredaran uang, distribusi atau pengiriman barang, 
pengemasan barang, kebutuhan tenaga kerja, dan mobilitas penduduk yang berkurang. Jumlah peredaran uang secara fisik di masyarakat menjadi berkurang karena transaksi pembayaran dapat menggunakan fasilitas transfer yang ada di bank-bank dan dapat dilakukan juga dengan menggunakan dompet digital yang sekarang banyak tersedia seperti OVO, paylater, DANA, linkAja, Kredivo, AkuLaku shopeepay, gopay dan lain-lain. Dampak lainnya dari pandemi COVID-19 ini menjadikan masyarakat menjadi lebih berhati-hati dan mengurangi transaksi dengan uang fisik sehingga menjadi salah satu faktor peningkatan transaksi online.

Dampak lain adalah pada distribusi barang yang juga terpengaruh dengan adanya peningkatan belanja online ini. Sektor ini mengalami peningkatan jumlah permintaan terhadap jasa logistik pengiriman barang ke seluruh Indonesia. Berdasarkan hasil penelitian MarkPlus terjadi peningkatan penggunaan jasa kirim selama masa bekerja dari rumah atau lebih dikenal dengan WFH (Work From Home) dan adanya pembatasan sosial yang mencapai lebih dari 50\%, peningkatan ini terjadi pada kelas menengah hingga 79,2\% (Ekasari, 2020). Hal ini memacu tumbuhnya bisnis dibidang logistik. Saat ini sudah banyak perusahaan logistik seperti Pos Indonesia, JNE, Tiki, J \& T, Sicepat, Anteraja, Shopee, Wahana, Paxel, Ninja Express, RPX, dan lain-lain. Selain itu jasa logistik instan yang bisa langsung sampai atau Layanan sehari sampai juga bisa menjadi pilihan dengan memanfaatkan gosend, grabsend, dan sebagainya. Banyaknya kemunculan jasa pengiriman barang ini menunjukkan bahwa peningkatan belanja online berpengaruh pada kebutuhan untuk mendistribusikan barang dengan cepat dan aman. Dengan bermunculannya jasa pengiriman barang ini membuka lapangan kerja baru untuk mendistribusikan barang-barang kepada peanggan.

Kebutuhan tenaga kerja untuk penjualan online dari sisi penjual lebih menghemat tenaga kerja karena tidak perlu berjaga seharian dan melayani pembeli yang datang. Namun tenaga kerja yang dibutuhkan bisa dialihkan fungsinya untuk administrasi yang mengurusi transaksi pembelian, administrasi penjualan, administrasi keuangan, pengemasan barang, dan petugas di gudang. Untuk pengiriman barang sudah ada fasilitas penjemputan dari ekspedisi sehingga lebih hemat tenaga dan waktu bagi penjual.

Dengan adanya belanja online ini bisa menekan mobilitas dan pergerakan warga untuk keluar rumah sehingga bisa ikut mensukseskan program pemerintah dalam mengendalikan menyebarnya COVID-19. Selain dampak positif tersebut ada juga dampak negatifnya dengan peningkatan transaksi online maka membutuhkan pengemasan akan barang-barang yang dikirimkan. Jika pedagang yang masih suka menggunakan plastik sebagai kemasan karena dianggap praktis dan tahan air namun meningkatkan pencemaran lingkungan. Karena plastik merupakan salah satu bahan yang susah untuk didaur ulang dan bisa menjadi salah satu penyumbang kerusakan lingkungan.

Selain itu dengan adanya perubahan pada cara konsumsi masyarakat ini dapat menekan mobilitas dan interaksi masyarakat secara langsung sehingga dapat berperan serta pada program pemerintah untuk menekan laju penyebaran virus COVID-19. Dengan melakukan belanja secara online memberikan berbagai keuntungan bagi masyarakat antara lain menghemat waktu, tenaga, dan biaya karena tidak perlu meninggalkan rumah untuk berbelanja dan mengeluarkan biaya untuk transportasi. Selain itu konsumen bisa leluasa untuk membandingkan harga barang antar penjul dan biasanya harga yang ditawarkan di e-commerce lebih murah jika dibandingkan dengan belanja langsung.

Bagi pemerintah dengan adanya peningkatan transaksi online memberikan keuntungan dari sisi penerimaan pajak karena mendapatkan Pajak Pertambahan Nilai (PPN) dan dapat meningkatkan pertumbuhan ekonomi secara nasional. Selain itu dapat mendukung program pemerintah untuk mengurangi penyebaran penyakit COVID-19 di Indonesia. E-commerce juga membantu pemerintah untuk memberikan dan meningkatkan pelayanankepada warga negara yang 
tinggal di daerah terpencil yang susah dijangkau seperti memberikan penyediaan obat-obatan, buku pelajaran, dan kebutuhan lainnya.

\section{PENUTUP}

Terdapat perbedaan jumlah pengunjung situs e-commerce pada masa sebelum pandemi COVID-19 dan selama masa pandemi COVID-19. Selama masa pandemi COVID-19 terjadi peningkatan jumlah kunjungan pada situs e-commerce terutama Shopee dan Tokopedia. Dengan peningkatan kunjungan pada situs e-commerce ini sangat berpengaruh pada sisi ekonomi seperti terjadi peningkatan transaksi keuangan secara online, permintaan jasa ekspedisi yang meningkat, kebutuhan bahan untuk mengemas barang juga meningkat, serta peningkatan kebutuhan tenaga kerja pada jasa ekspedisi.

Berbelanja online dapat menekan mobilitas masyarakat sehingga diharapkan dapat membantu pemerintah dalam menekan laju penyebaran penyakit Covid19. Oleh karena itu diharapkan masyarakat tetap memenuhi kebutuhannya dengan berbelanja online. Bagi penjual diharapkan dapat memberikan pelayanan terbaik bagi pembelinya seperti kecepatan waktu dalam pelayanan, kualitas barang yang diberikan, dan pengemasan barang yang aman. Bagi pemilik e-commerce diharapkan dapat menjamin konsumen untuk mendapatkan pelayanan terbaik dan keamanan dalam bertransaksi. Penelitian selanjutnya bisa dilakukan untuk melihat pola konsumsi masyarakat dengan melihat barang-barang yang banyak dibeli dan untuk mencari faktor-faktor yang yang mendukung e-commerce sehingga omset penjualannya menjadi meningkat.

\section{Ucapan Terimakasih}

Penulis mengucapkan terima kasih kepada BPSDMP Kominfo Jakarta atas dukungan yang diberikan sehingga bisa menyelesaikan tulisan ini dan semoga tulisan ini bisa bermanfaat.

\section{DAFTAR PUSTAKA}

Ayu, S., \& Lahmi, A. (2020). Peran e-commerce terhadap perekonomian Indonesia selama pandemi Covid19. Jurnal Kajian Manajemen Bisnis, 9(2), 114. https://doi.org/10.24036/jkmb.10994100

Dinisari, M. C. (2020, April 17). E-commerce Dorong Perekonomian Indonesia, selama Pandemi Covid-19. Bisnis.Com. https://ekonomi.bisnis.com/read/20200417/12/1228750/e-commerce-dorongperekonomian-indonesia-selama-pandemi-covid-19-

Ekasari, M. A. (2020). Industry roundtable Surviving The Covid-19, Preparing The Post, Logistics Industry Perspective. In MarketPlus.Inc.

Harahap, D. A. (2018). Perilaku Belanja Online Di Indonesia: Studi Kasus. JRMSI - Jurnal Riset Manajemen Sains Indonesia, 9(2), 193-213. https://doi.org/10.21009/jrmsi.009.2.02

Heryana, A. (2017). Uji McNemar dan Uji Wilcoxon (Uji Hipotesa Non-Parametrik Dua Sampel Berpasangan). Catatan Ade Heryana, May, 3-8. https://doi.org/10.13140/RG.2.2.17682.48325

Insight, I. (2021). Peta $E \square$ Commerce Indonesia.

Išoraite, M., \& Miniotienè, N. (2018). Electronic Commerce: Theory and Practice. IJBE (Integrated Journal of Business and Economics), 2(2), 73. https://doi.org/10.33019/ijbe.v2i2.78

Khan, A. G. (2016). Electronic Commerce: A Study on Benefits and Challenges in an Emerging Economy. Type: Double Blind Peer Reviewed International Research Journal Publisher: Global Journals Inc, $16(1)$.

Kurtz, M. (2016). Introduction to E-commerce: Combining Business and Information Technology. In BookBoon. bookboon.com. https://irp-cdn.multiscreensite.com/1c74f035/files/uploaded/introductionto-e-commerce.pdf

Kusumatrisna, Adam Luthfi; Rozama, Nia Anggraini; Syakilah, Adriyani; Wulandari, Vera Citra; Untari, Rima; Sutarsih, T. (2020). Statistik e-Commerce 2020 (Vol. 148). Badan Pusat Statistik.

Laming, S. (2020). Tren E-Commerce Pada Era Pandemi COVID-19. In Jurnal Penelitian Humano (Vol. 11, Issue 2, pp. 55-63).

Majchrzak-Lepczyk, J. (2021). Value for the Customer in E-commerce. 2035(26), 139-149. https://doi.org/10.1007/978-3-319-91668-2_12 
Montolalu, C., \& Langi, Y. (2018). Pengaruh Pelatihan Dasar Komputer dan Teknologi Informasi bagi GuruGuru dengan Uji-T Berpasangan (Paired Sample T-Test). Jurnal Matematika Dan Aplikasi d'CARTESIAN, 7(1), 44. https://doi.org/10.35799/dc.7.1.2018.20113

Muktaf, Z. M. (2016). E commerce sebagai Agen Konsumsi di Era Media Baru. International Conference Social Politic Universitas Muhamadiyah Yogyakarta, 2016, 26-28.

Muttaqin, Z. (2012). Facebook Marketing Dalam Komunikasi Pemasaran Modern. Teknologi, 1(2), 103109. https://doi.org/10.26594/teknologi.v1i2.63

Pradana, M. (2015). Klasifikasi Jenis-Jenis Bisnis E-Commerce. Jurnal Neo-Bis, 9(2), 32-40.

Sampson, M. A. G. (2019). Analisis Statistik Menggunakan JASP Buku Panduan Untuk Mahasiswa JASP $v$. 0,11 (Vol. 2). https://doi.org/10.6084/m9.figshare.9980744

Supratman, L. P., \& Rachmansyah, M. (2020). Peran Media Instagram dalam Memasarkan Produk Fashion Dollies. Jurnal Studi Komunikasi Dan Media, 24(1), 73. https://doi.org/10.31445/jskm.2020.2865

Susanto, A., Sari, C. A., Moses, D. R. I., Rachmawanto, E. H., \& Mulyono, I. U. W. (2020). Implementasi Facebook Marketplace untuk Produk UMKM sebagai Upaya Peningkatan Pemasaran dan Penjualan Online. Abdimasku : Jurnal Pengabdian Masyarakat, 3(1), 42. https://doi.org/10.33633/ja.v3i1.64

Taher, G. (2021). E-Commerce: Advantages and Limitations. International Journal of Academic Research in Accounting Finance and Management Sciences, 11(1), 153-165. https://doi.org/10.6007/IJARAFMS

Wibowo, E. A. (2016). Pemanfaatan Teknologi E-Commerce Dalam Proses Bisnis. Equilibiria, 1(1), 95-108. 
JURNAL STUDI KOMUNIKASI DAN MEDIA

Vol. 25 No. 2 Desember 2021 Hal : 191 - 202 